Vol.45, N. 2 : pp. 115 - 124, June 2002

ISSN 1516-8913 Printed in Brazil

BRAZILIAN ARCHIVES OF BIOLOGY AND TECHNOLOGY

AN INTERNATIONAL JOURNAL

\title{
N:Si:P Atomic Ratio in the Santa Cruz Channel, Itamaracá- PE (Northeast Brazil): a Nyctemeral Variation
}

\author{
Manuel de Jesús Flores Montes; Silvio José de Macêdo and Maria Luise Koening* \\ Department of Oceanography; UFPE; Av. da Arquitetura s/n; Cidade Universitária; Recife-PE; CEP 50.9670-901
}

\begin{abstract}
Studies were carried out on the Inlets of Orange and Catuama at the Santa Cruz Channel, Itamaracá-PE, in the rainy and dry seasons, in a nyctemeral cycle, and in a transversal profile, with intervals of three hours between collections. The objective was to determine the spacial and temporal variation of the N:Si:P atomic ratio, and its possible inter-relations and dependencies, as well as the influence of the hydrodynamism provoked by the variation of the tides at different times of the year. Nitrite- $N$ and nitrate- $N$ were higher in the rainy season, while ammonia- $N$, phosphate-P and silicate-Si were higher in the dry season, which indicated different results than previous studies. The N:P atomic ratio was lower than 16:1, in all seasons and stations, being highest in the rainy season at Inlet Orange. The Si:P atomic ratio was always high. During the observed nyctemeral cycles, the main factors influencing the composition of the physical, chemical and biological parameters were the tide cycles and the meteorological parameters.
\end{abstract}

Key words: N:Si:P atomic ratio, dissolved nutrients, estuary, nyctemeral variation

\section{INTRODUCTION}

The importance of determining the N:Si:P atomic ratio in an estuarine environment is in the necessity of establishing which is the limiting nutrient for the primary production and what is the productivity that will be supported in the estuary. It is also important to confirm if this ratio is constant or variable, as it is a very dynamic environment, and if there exists a specific class of primary producers that could be benefited.

Coastal marine environments are well known for their high biomass production and capacity to sustain important fisheries around the world. It is generally accepted that the maintenance of the ecological balance and high productivity in coastal and ocean environments is directly related to the nutrients supplied from various sources, including estuary coastal-fluvial exchanges, upwellings, precipitation, nitrogen fixation, regeneration of nutrients, etc. These factors affect the coastal production dynamics, that help to replace the nutrients lost to death and/or decomposition (Flint, 1985).

The consequence of the enrichment of the estuarine areas by the soil lixiviation and the accumulation of nutrient salts from rivers is their transformation into areas of high eutrophication. This processes, together with the interaction between physical forces and biological activity (Dustan \& Pinckney, 1989), generate great

\footnotetext{
* Author for correspondence
} 
densities of phytoplankton populations (Ketchum, 1967).

Teixeira \& Gaeta (1991) mentioned that one of the fundamental aspects for the obtainment of data about the primary production of an ecosystem with greater accuracy and significance for the making of models, was the information obtained from the nyctemeral periodicity ( 24 hour cyclical activities comprising both day and night), not only of phytoplankton, but also of the particular environmental characteristics. Teixeira \& Gaeta (1991) were the first to suggest the existence of the nyctemeral rhythm in the photosynthesis activity.

The estuarine region of Itamaracá stands out in the coastal strip of Pernambuco for its high productivity, being an area of intense fishing activity, besides offering a wide range of possibilities for the installation of aquacultural projects. Due to its location and natural beauty, it has also been a target of indiscriminate occupation by the industrial, real state and tourist sectors, increasing consequently its population density. The main nutrient salts dissolved in the water, are the dissolved inorganic nitrogen compounds (DIN), phosphate (DIP) and silicate, which condition the development and production of the phytoplanktonic organisms, as they are the base of the trophic chain. Total production of phytoplankton surged higher or lesser animal production (Boynton et al. 1982). Escaravege et al. (1995), considered that the irradiation and the nutrients, were the essential factors that controlled the primary production and fish production.

The main nutrient sources in an estuarine system are the fluvial discharges and terrestrial drainage provoked by the rains, the deposited and regenerated nutrient upwelling in the sediments, and the marine coastal waters. More recently, there have been increments of nutrients originating from anthropogenic activities, such as the precipitation of solids in suspension thrown into the atmosphere by pollution, which provoke eutrophication in various coastal regions, as well as the so called "new" primary production (Smith, 1984; Fan \& Jin, 1989; Chester, 1990; Escaravage et al.; Paerl, 1995; Rasmussen, 1995). The concentration of nutrients varies distinctively in time and space, and even between tide cycles (Flores Montes, 1997). For Grzetic et al., (1991), the variation in the estuary of the river Krka
(Adriatic) can be explained by the combined influences of different processes, such as biological assimilation of the nutrients/ cycle of regeneration, sweet water discharge, anthropogenic contribution, horizontal and vertical advection, and others; some of these processes predominate over others, in different parts of the water column and/or different zones of the estuary.

An understanding of the chemical factors that regulate the biomass and the production of the whole aquatic ecosystem, requires a detailed evaluation of the factors that control the biodisponibility of the essential nutrients. For phosphorous, it is more complicated, due to the difficulties of distinguishing between inert and reactive phosphate. The essential source of biologically available dissolved phosphate, is the deterioration of continental rocks, from where there is a great dissemination of insoluble minerals, representing approximately $0.1 \%$. Close to $5-10 \%$ of the phosphorous that comes from the erosion of continental rocks, is transported to the oceans in dissolved form, the rest is probably transported as inert phosphorous in fluvial granulated debris (Froelich, 1988). On the other hand phosphorous is a highly reactive element, reacting rapidly while in solution, with a wide variety of surfaces. It is associated and liberated by particles, through a complex series of absorption and disassociation reactions (Millero \& Sohn, 1992).

Due to the existence of phosphate natural deposits in the whole coastal region between Olinda and Itamaracá. Macêdo (1974) suggested that the phosphate concentrations in the Santa Cruz Channel were directly influenced by fluvial transports and by pluviometric precipitation. Passavante (1979), explains that the occurrence of phosphorite in the coastal stretch of the region at the base of the calcareous Gramame, were largely responsible for the natural supply of phosphorous in the Santa Cruz Channel.

Millero \& Sohn explain that in 1934, Redfield initiated research on the ratios of the concentrations of dissolved oxigen, carbon dioxide, nitrate and phosphate in sea water, based on the chemical composition of the phytoplankton. According to Boulahbid \& Minster (1989), these ratios could change according to the variation of the dissolved nutrients. This was also confirmed 
by studies done by Parsons et al. (1984) and Rhee (1978), which proposed that it would be more appropriate to place the $\mathrm{N}: \mathrm{P}$ ratio in an interval of 10:1 to $20: 1$.

Howarth et al. (1988) observed that the correlation between nitrogen and the primary production was better for the estuaries that received nutrient concentrations with a smaller N:P ratio than for the one studied by Redfield - which is valid for the majority of estuaries. Supposedly, estuaries that received nutrient concentrations with a high $\mathrm{N}: \mathrm{P}$ coefficient, were limited by the phosphorous, and only those with a low coefficient are limited by the nitrogen (Boynton et al., 1982). Therefore, if the phytoplankton demand for available nutrients was high, either nitrogen or phosphorous could be exhausted first, depending on the environmental relation.

According to Rhee (1978), the best cellular N:P ratio would be specific, which would be of great ecological importance in that, in a specific environment, the growth of one species could be limited by one nutrient, while the growth of other species could be regulated by other nutrients. The severity of each limitation could determine the result of the competition, and the interval between the relations could determine the level in which the coexistence is possible.

\section{AREA DESCRIPTION}

The territory of Pernambuco, located in the Northeast of Brazil has a thin and elongated configuration, and its $187 \mathrm{~km}$ coast-line is one of the shortest in the Brazilian territory. The island of Itamaracá $\left(7^{\circ} 34^{\prime} 00^{\prime \prime}, 7^{\circ} 55^{\prime} 16^{\prime \prime} \mathrm{S}\right.$ e $34^{\circ} 58^{\prime} 48^{\prime \prime}$, $34^{\circ} 52^{\prime} 24^{\prime \prime} \mathrm{W}$ ), is situated $50 \mathrm{~km}$ North from Recife, capital of the State of Pernambuco, on highway BR-101. This area is characterized by a tropical climate of Am' type, in Koeppen's system, with transition to As', as it distances itself from the coast. The evaporation rate is inferior to that of precipitation, having a positive annual balance. The air temperature reaches an absolute maximum of $34^{\circ} \mathrm{C}$ and minimum of $20^{\circ} \mathrm{C}$, being in average $27^{\circ} \mathrm{C}$. The Santa Cruz Channel which separates the island from the coast, has an extension of $22 \mathrm{~km}$, and variable widths of 0.6 to $1.5 \mathrm{~km}$. The whole area is very shallow, with varying depths in low tide from around $4-5 \mathrm{~m}$, to less than $2 \mathrm{~m}$ in many places. This channel connects with the sea in the North at Inlet Catuama and in the South at Inlet Orange, locations where the depths can reach up to $10 \mathrm{~m}$ or more, as they are the most sensitive sections to the movement of the tides, which are semi-diurnal. The channel receives continental influence through a number of smaller rivers, the main ones being: Catuama, Carrapicho, Botafogo and Congo to the North; and Igarassu and Paripe (the only significant water source, originating from the island of Itamaracá) to the South. The hydrographic basin has a total of $730 \mathrm{~km}$.

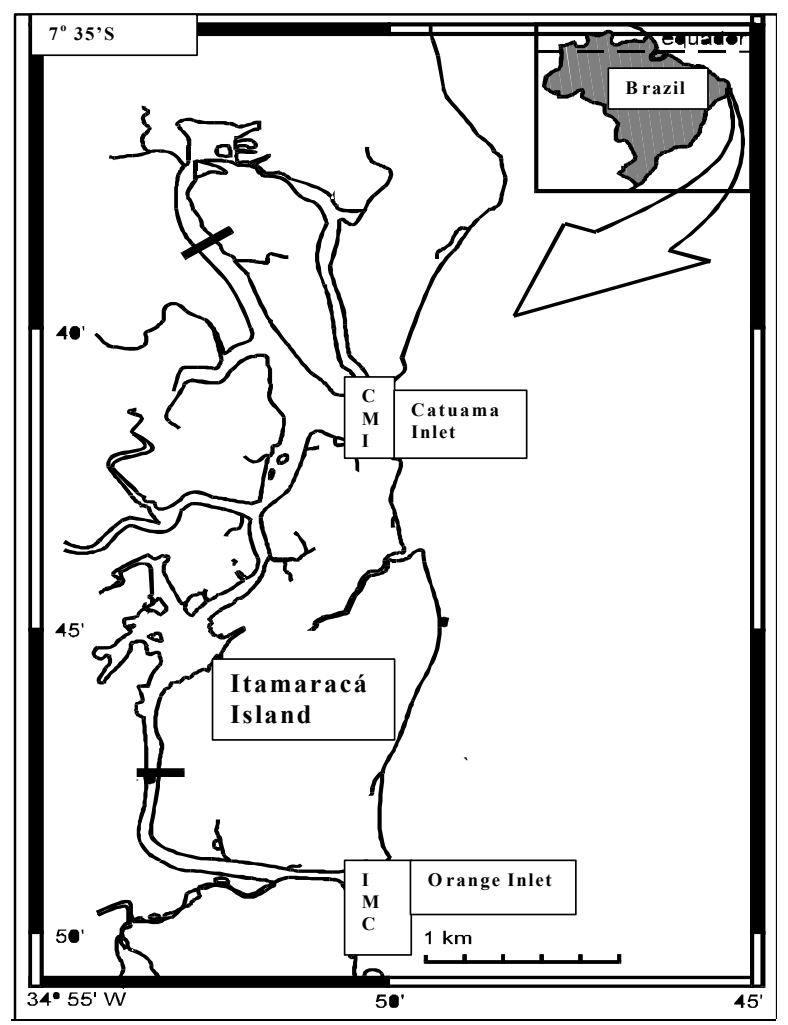

Figure 1 - Map of area and sampling stations. (I: Island Station; M: Middle Station and C: Continent station)

The salinity of the channel waters suffers modifications along the whole year, in response to the local meteorological conditions, according to Macêdo et al. (1973), being effected to a lesser degree in areas closer to the interior. The salinity oscillates between a eurihaline zone in the dry season, and mesohaline and polihaline zones, during the rainy season.

Medeiros (1991) viewed the Itamaracá system as an estuary-lake, type-1, following the criteria of 
the dynamic classification for estuaries, developed by Hansen \& Rattray (1966), which was characterized by a flow of sea bound water (from the surface to the bottom) and a transport of salts moving predominantly upstream, dominated by diffusive processes. In the rainy season it got close to the subtype 1a (moderate stratification), while in the dry season it got closer to the subtype $1 b$ (well mixed).

\section{MATERIAL AND METHODS}

Studies on the nyctemeral variation of the hydrological parameters and of the phytoplankton composition and density of the waters in the Santa Cruz Channel (Itamaracá-PE) were carried out during periodic tide cycles in two transects (Inlets of Orange and Catuama), representing a nyctemeral cycle, with intervals of three hours between each sampling during the rainy and dry seasons.

For the sampling carried out at Inlets Orange and Catuama (Figure 1), two transects were established, where three sampling stations were equally distributed along notable terrestrial reference points, denominated island (I), middle (M ) and continent (C) -sampling at three depth levels (surface, intermediate and deep layer).

The samplings of the hydrological material were carried out with Nansen oceanographic bottles of $1.3 \mathrm{~L}$ capacity, from which sub-samples of $1 \mathrm{~L}$ were extracted in polyethylene bottles, and taken immediately to the laboratory, where they were filtered using the vacuum system, with Sartorius GF/C filters (for determination of ammonia, nitrite, nitrate and phosphate) and cooled for posterior analysis.

The main inorganic salt nutrients dissolved in the water were determined through techniques described by Strickland \& Parsons (1972) and Grasshof et al. (1983). Ammoniac nitrogen (N$\mathrm{NH}_{3}{ }^{-}+\mathrm{N}^{-} \mathrm{NH}_{4}{ }^{+}$), hereafter refereed to as ammonia) was determined by blue-indophenol, nitrite was done by diazotation method and phosphate was done by the molybdenium blue method (Grasshoff et al. 1983). Nitrate was determined by reduction in a cadmium column followed by diazotation and silicate formed silicomolibdic complex, when reduced, formed the blue colour (Strickland \& Parsons, 1972).

The relation used was that which Redfield (1934) and Deggobis (1990), proposed for N:P, of 16:1.
Legovic et al. (1991) gave reference to this relation, including silicate: $\mathrm{N}: \mathrm{SI}: \mathrm{P}=16: 15: 1$.

\section{RESULTS}

In this study, the concentrations of $\mathrm{N}, \mathrm{P}$ and $\mathrm{Si}$, registered during the studied nyctemeral cycle were: in Inlet Orange a maximum of the ammonia-N was $6.83 \mu \mathrm{mol} . \mathrm{L}^{-1}$, and nitrite was $1.27 \mu \mathrm{mol} . \mathrm{L}^{-1}$, during a dry season. The nitrate-N maximum was $6.73 \mu$ mol. $\mathrm{L}^{-1}$ in the rainy season. The phosphate-P and silicate-Si were higher in a dry season with $6.87 \mu$ mol. $\mathrm{L}^{-1}$ and $99.98 \mu \mathrm{mol}^{\mathrm{L}} \mathrm{L}^{-1}$, respectively.

A inlet Catuama, a maximum of the ammonia-N was $3.93 \mu \mathrm{mol} . \mathrm{L}^{-1}$ and the nitrite-N, during a dry season. The nitrate-N maximum was $3.98 \mu$ mol. $^{-1}$ in the rainy season. The phosphate-P and silicateSi maximum in dry season were $3.94 \mu \mathrm{mol} . \mathrm{L}^{-1}$ and $47.50 \mu \mathrm{mol} . \mathrm{L}^{-1}$, respectively.

In the rainy season, at Inlet Orange, atomic ratio variation at sampling station I was from 3.5:1 to 8.6:1; at station $M$ from 2.0:1 to 8.3:1; and at station $\mathrm{C}$ from $2.1: 1$ to $12.8: 1$, having an average of 6.0:1. At Inlet Catuama, the variation oscillated in station $\mathrm{I}$, from $2.1: 1$ to $12.8: 1$; in station $\mathrm{M}$, from 2.2:1 to $16: 1$; and in station $C$, from 1.3:1 to 27.5:1, having an average of 6.9:1.

In the dry season, at Inlet Orange, the ratio variation at station I was from $0.4: 1$ to $7.3: 1$; from 1.0:1 to $4.6: 1$ at station $\mathrm{M}$; and from $0.5: 1$ to 18.8:1 at station $\mathrm{C}$, having an average value of 2.4:1. At Inlet Catuama, the variation was from 1.4:1 to $29.0: 1$ at station I; from $0.5: 1$ to $21.0: 1$ at station $\mathrm{M}$; and from $0.9: 1$ to $25.1: 1$ at station $\mathrm{C}$, having an average value of 7.6:1. Generally the nyctemeral variation was fairly irregular, specially in the dry season.

The Si:P ratio was always high, being at Inlet Orange an average of approximately 27:1 in the rainy season, and 21:1 in the dry season. At Inlet Catuama, the average variation was of 30:1 in the rainy season, and of 44:1 in the dry season, the silicate-Si not being a limiting factor therefore, for the development of the diatoms (Figures 2 and 3). 


\section{DISCUSSION}

Boynton et al., (1982), explained that it was the nitrogen rather than the phosphorous, that was most important in the regulation of phytoplanktonic production in an estuarine system, and that after observing a great variety of estuaries, it was evident that the nitrogen was less abundant than the phosphorous during the peak productivity periods. They also observed a great annual variation, especially in the group of estuaries that were influenced by rivers. In Chesapeake's Bay, USA, for example, during periods of great flux, the ratio was very high, higher than 60:1, which was due to a great concentration of nitrogen $\left(50 \mu \mathrm{mol} . \mathrm{L}^{-1}\right)$. In the summer (peak period for primary production), the ratio was extremely reduced, which indicated that mechanisms were activated that rapidly removing DIN or add DIP in the water column, such as, denitrification processes, deposits of nitrogen particulates or the accretion of phosphorous from anoxide sediments. At Inlet Orange, the maximum atomic ratio was due a lesser concentration of phosphate-P $\quad(>0.5$ $\mu$ mol. $\left.L^{-1}\right)$.

The average atomic ratios $\mathrm{N}: \mathrm{Si}: \mathrm{P}$ obtained, being the first measurements done in this region, were, 6.1:26.7:1 and 2.1:20.7:1, at Inlet Orange, and 6.9:30.9:1 and 7.6:41.8:1 at Inlet Catuama in the rainy and dry seasons respectively, which confirmed that the nitrogen was the limiting nutrient in the estuarine regions of Itamaracá.

The silicate-Si was not at any time limiting for the production and development of diatoms, having higher disponibility at Inlet Catuama, where smaller densities of diatoms were determined than at Inlet Orange. The greater ratios in the stations closer to the continent (stations C \& M), were indicative of the influence of the terrestrial contribution of nitrogen in the region. The nyctemeral variation was mainly due to decrease in the amount of other nutrients and an increase in the concentration of silicate-Si.

In relation to the $\mathrm{N}: \mathrm{P}$ coefficient, in the rainy season it was higher in average than in the dry season. This explained the high phytoplankton densities produced during the rainy season at Inlet Orange, and its lower densities during the dry season. At Inlet Catuama, the ratios were equivalent in both seasons, but the higher densities during the dry season could have been a consequence of the dominance of the phytoflagellates over the diatoms, because as they were cells of smaller dimensions and consequently of higher surface/volume ratio, they were able to rapidly absorb and adapt to the nitrogen concentrations.

The flora composition of Inlet Orange showed the highest number of abundant and very frequent species, as well as the highest total and individual densities, highest average density and most significant "blooms". On average, the total phytoplankton densities were higher in the rainy at Inlet Catuama $2.38 \times 10^{6}$ cel. $L^{-1}$ in the dry season with a maximum of $4.46 \times 10^{6}$ cel. $\mathrm{L}^{-1}$ and season, which indicated that this Inlet contained more favorable environmental conditions.

This was due to the peculiar characteristics of each Inlet. For example, Inlet Orange had a lesser dilution of its more fertile estuarine waters, by the less fertile marine waters. It was also shallower, which permited a faster and more constant exchange of nutrients between the sediments and the water column, increasing the concentration of dissolved nutrients. In addition, at Inlet Orange there was more influence from human activity, which consequently increased the anthropogenic wastes, contributing to the increase of nutrient concentration and the $\mathrm{N}: \mathrm{P}$ ratio, among other things. It could also be considered, that when the continental waters arrive to Inlet Catuama, they have had their dissolved nutrient concentrations fairly exhausted along the trajectory by chemical and biological processes (Flores Montes, 1997).

These processes also reflect in the composition of the main groups of phytoplankton. At Inlet Orange, for example, a high diatom production was registered during the rainy season, which could be the result of lower salinity (Koening, 1983) and higher 
St. I (rainy season)

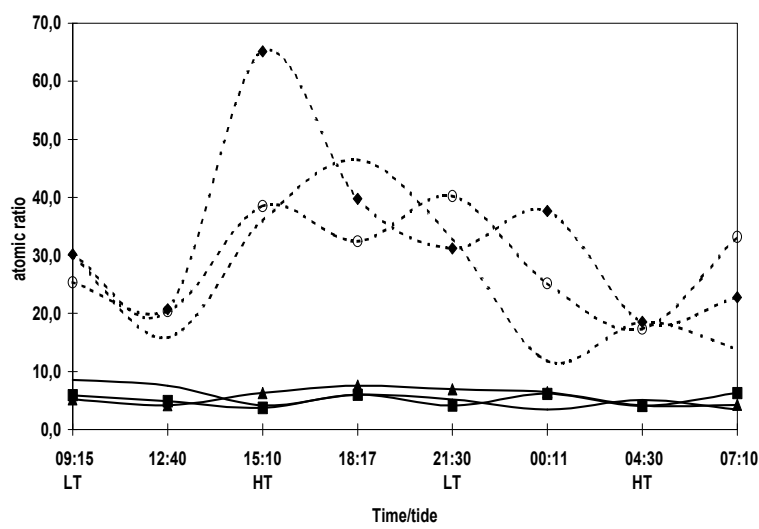

St. M

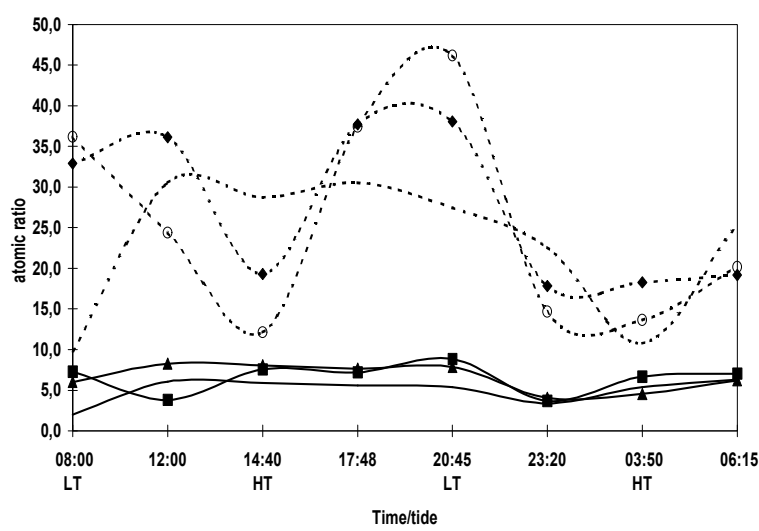

St. C

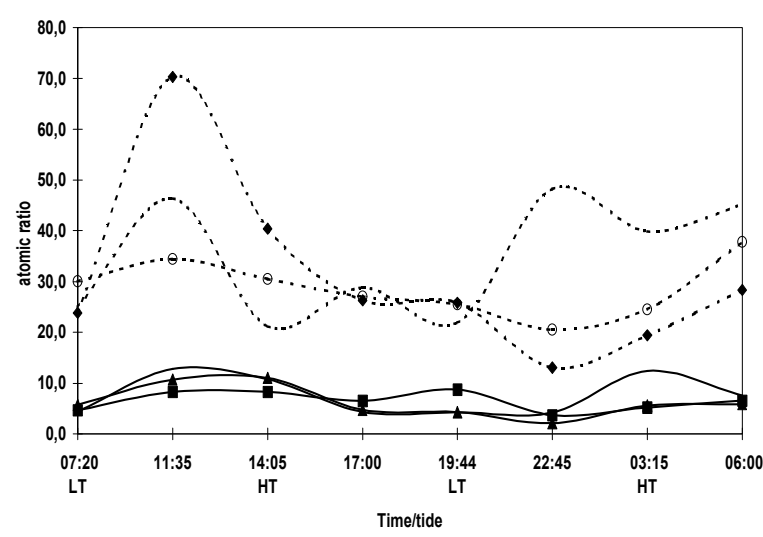

St. I (dry season)

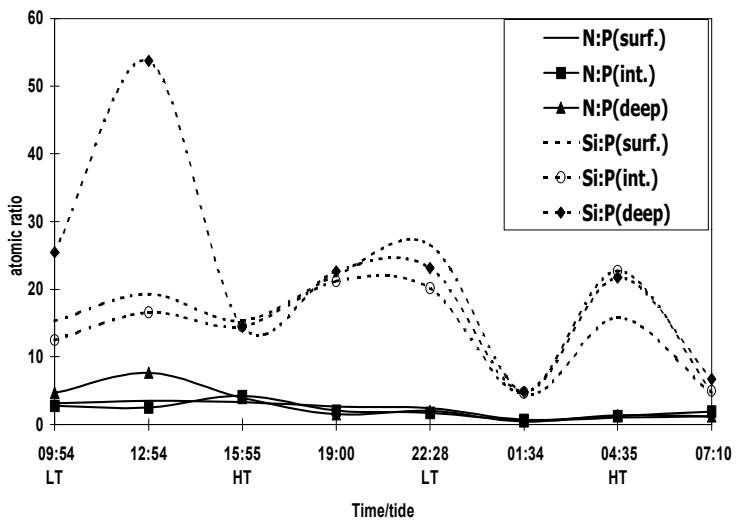

St. M

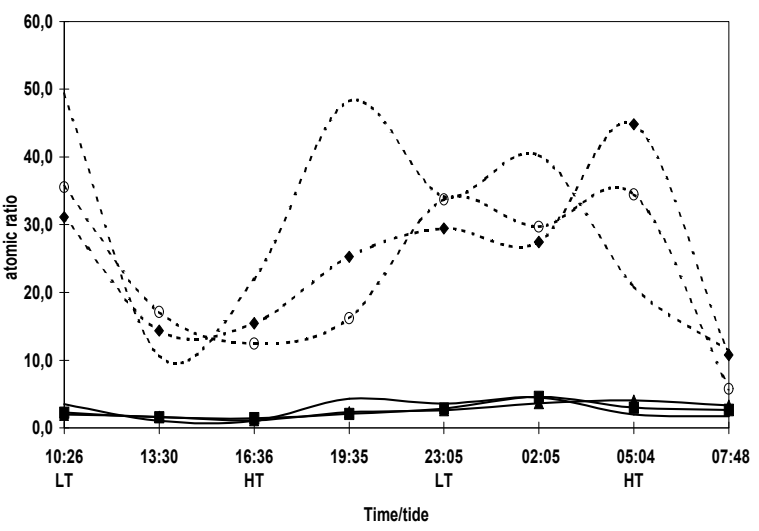

St. C

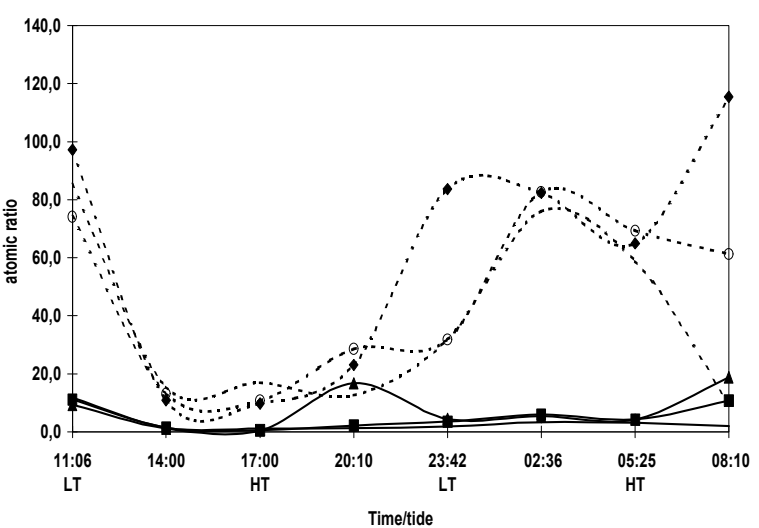

Figure 2 - N:P and Si:P atomic ratio in Orange Inlet (surface, intermediate and deep layer). 
St. I (rainy season)

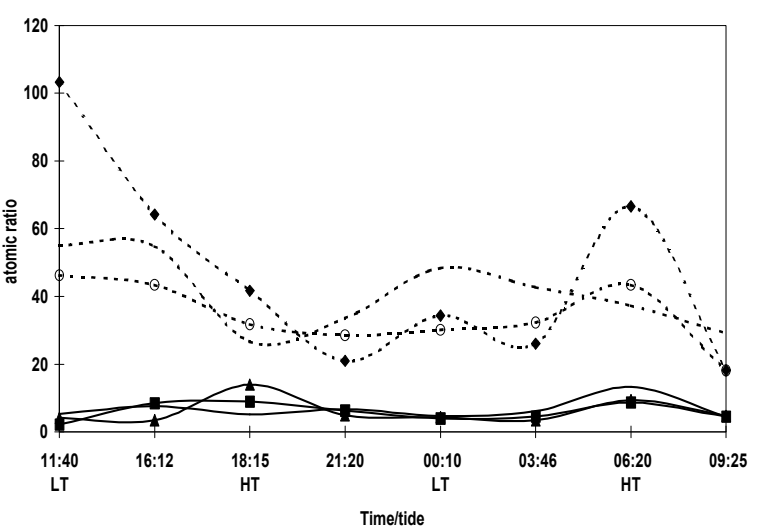

St. M

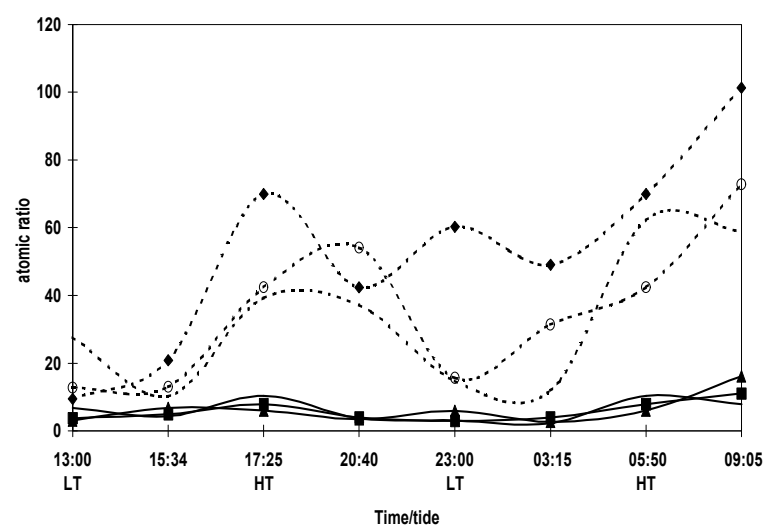

St. C

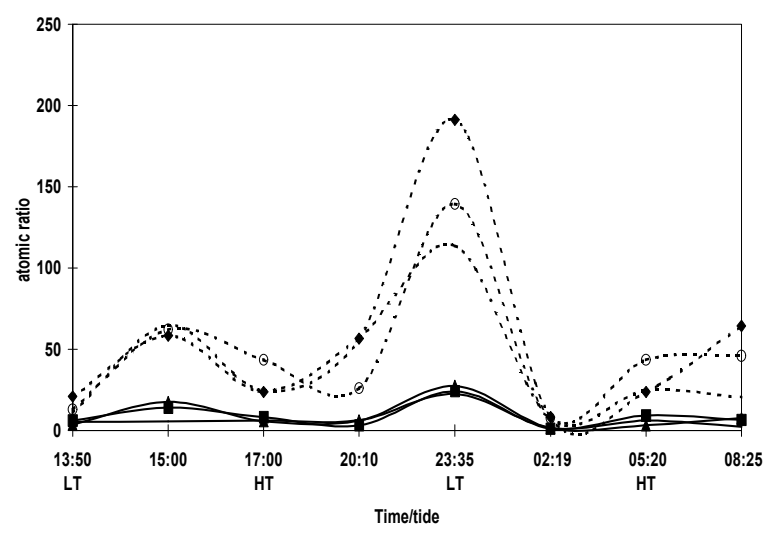

St. I (dry season)

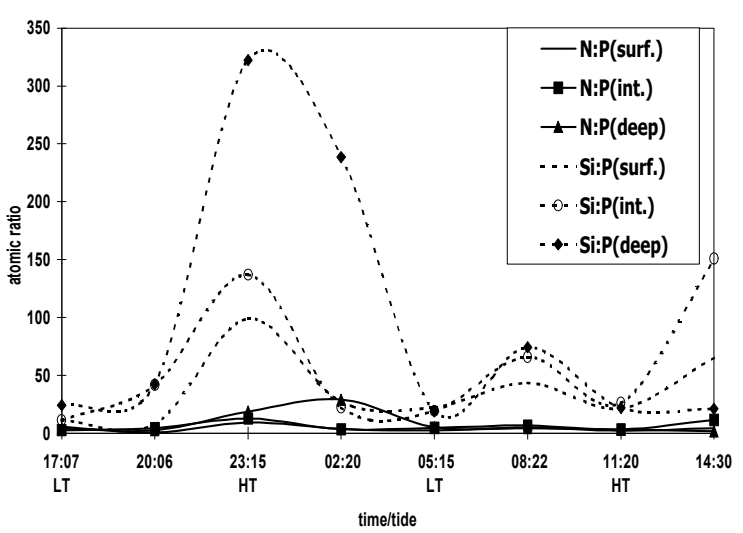

St. M

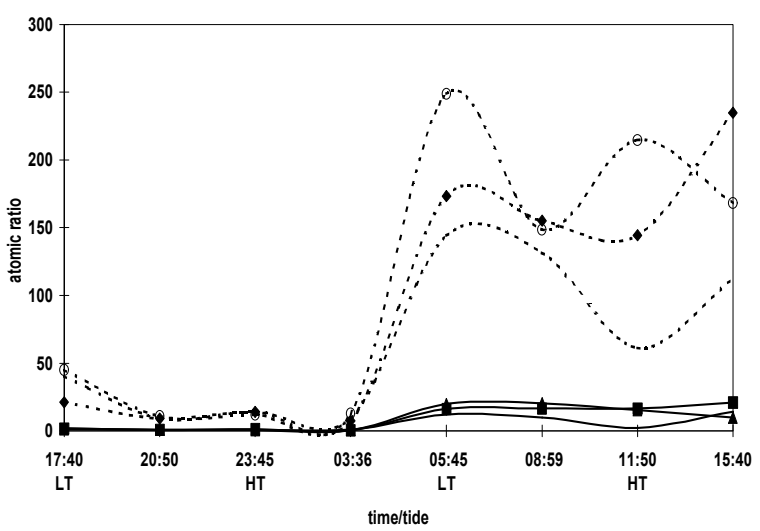

St. C

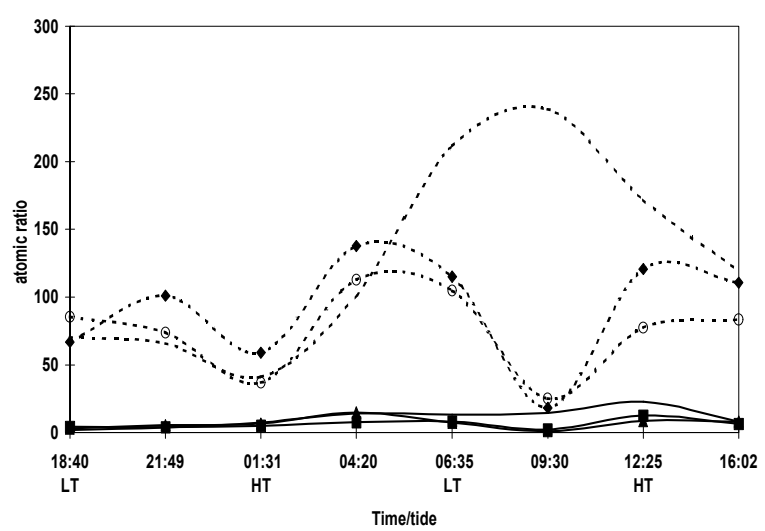

Figure 3 - N:P and Si:P atomic ratio in Catuama Inlet (surface, intermediate and deep layer). 
nutrient quantities during that time. In the dry season, the N:P ratio decreased, which could be the result of the reduction of nutrients from continental origin. The increased transparency, could have helped the development of phytoflagelattes, which were dominant during the dry season.

Considering that both Inlets were communication accesses between the estuarine system of Itamaracá and the coastal region, and that they were points that received sweet water discharges as well as great influence from marine water, the variation of salinity in these locales permitted that eurihaline species found a high quantity of dissolved nutrients. This was specially true at Inlet Orange, where the N:P ratio presented the highest values in the rainy season, aiding phytoplankton development. At Inlet Catuama, this disponibility was lower as it presented a lower N:P ratio, which favored phytoflagelatte development in the dry season.

The intervals of density phytoplanktonic variation showed that in the nyctemeral cycle the densities presented great oscillations. First because there were fairly accentuated variations in the physical aspects, like tide cycles, insolation and salinity in the rainy season. Second because there were oscillations in the chemical conditions - as nutrient increments or depletions due to fluvial or pluviometric flux, sedimentation or regeneration inside the estuary and by the phytoplankton absorption, or absorption by particulate or dissolved chemical compounds that altered the $\mathrm{N}: \mathrm{P}$ ratio (during a period of very low coefficient, only some species were able to absorb nutrients in low concentrations, like the nanoplankton). And third, through the biological pressures - as favorable conditions for the occurrence of "blooms", or as disfavorable, inducing the disappearance of phytoplankton through the grazing provoked by the zooplankton that was capable of consuming great quantities of phytoplanktonic cells (Legendre \& Rassoulzadegan, 1995).

The dominance between the organisms during both seasons in both Inlets was divided between the phytoflagelattes and some species of diatoms and were probably induced by the oscillations in the $\mathrm{N}: \mathrm{P}$ ratios and aided by the high silicate-S concentrations.
The phytoflagelatte densities were proximate in both Inlets, dominating and being very frequent. A $100 \%$ increase was registered between the rainy and the dry seasons, which could have been provoked by the preference of higher salinities, and/or also by the high surface/volume ratio, which increased the capacity to absorb nitrogen more rapidly and in low quantities.

The results hereby presented indicated that a small variation existed in the composition of the dominant species, either as a response to natural cycles of species alternation or as a reaction from external influences such as non-natural increments of domestic and/or industrial pollution, which could severely affect the N:P coefficient. This could only be made certain by comparing the results of different research studies on the possible causes of nutrient variation, carried out throughout a number of decades.

\section{CONCLUSIONS}

1. The concentrations of nitrite- $\mathrm{N}$ and nitrate- $\mathrm{N}$ were higher during the rainy season. The concentrations of ammoniacal-N, phosphate-P and silicate-S were higher during the dry season indicating that other processes existed besides the continental flux that control the disponibility of the main dissolved nutrients.

2. The Si:P atomic ratio was high, indicating that the silicate wasn't at any moment a limiting factor for diatom development.

3. The low $\mathrm{N}: \mathrm{P}$ atomic ratio proved that the nitrogen was a limiting factor for the phytoplankton development in this region.

4. Phytoplankton densities were generally higher at Inlet Orange when compared with Inlet Catuama

5. The N:Si:P atomic ratio was higher during the rainy season in Inlet Orange, conditioning a better development of the diatoms, the most frequent and dominant group.

\section{RESUMO}

Estudos nas Barras Orange e Catuama do Canal de Santa Cruz, Itamaracá-PE, foram realizados 
durante os períodos chuvoso e seco, num ciclo nictemeral, com intervalo de 3 horas entre as coletas, numa secção transversal. O objetivo foi a determinação da variação espacial e temporal da relação N:Si:P, suas possíveis inter-relações e dependências, bem como a influência das condições hidrodinamicas locais, influenciadas pela variação das marés em diferentes períodos do ano. Nitrito-N e nitrato-N, foram mais elevados no período chuvoso, enquanto que amônia-N, fosfato-P e silicato-Si, foram no período seco, sendo este resultado diferente de pesquisas anteriores. A relação $\mathrm{N}: \mathrm{P}$ foi menor que 16:1, nos diferentes períodos e estações, sendo porém, mais elevada no período chuvoso e na barra Orange, enquanto que a relação $\mathrm{Si}: \mathrm{P}$ esteve sempre superior a 15:1. Neste estudo, o nitrogênio foi $o$ nutriente limitante para $o$ fitoplâncton nesta área. Durante os ciclos nictemerais observados, os principais fatores que influenciaram a composição dos parâmetros físicos, químicos e biológicos foi o ciclo de marés e parâmetros meteorológicos.

\section{REFERENCES}

Boulahdid, M. and Minster, J. F. (1989), Oxygen consumption and nutrient regeneration ratios along isopycnal horizons in the Pacific Ocean. Marine Chemistry, 26 : (2), 133-153.

Boynton, W. R.; Kemp, W. M. and Keefe, C. W. (1982), A comparative analysis of nutrients and other factors influencing estuarine phytoplankton production. In- Estuarine Comparisons, Ed. V. S. Keneddy. Academic Press, London. pp. 69-90.

Chester, R. (1990), Marine Geochemistry. Chapman \& Hall, London.

Degobbis, D. (1990), A stoichiometric model of nutrient cycling in the northern Adriatic Sea and its relation to regeneration processes. Marine Chemistry, 29 : (2/3), 235-253.

Dustan, P. and Pinckney Jr., J. L. (1989), Tidally induced estuarine phytoplankton patchiness. Limnol. Oceanogr., 34 : (2), 410 - 419.

Escaravage, V. et al. (1995), The development of a Phaeocystis bloom im a mesocosm experiment in relation to nutrients, irradiance and coexisting algae. Ophelia, 42, 55-74.

Fan, A. and Jin, X. (1989), Tidal effect on nutrient exchange in Xiangshan Bay, China. Marine Chemistry, 27 : (3/4), 259-281.
Flint, R. W. (1985), Coastal ecosystem dynamics: relevance of benthic processes. Marine Chemistry, 16 : (4), 351-367.

Flores Montes, M. de J. (1997), Variação nictemeral do fitoplâncton e parâmetros hidrológicos no Canal de Santa Cruz, Itamaracá, PE. Dissertação (Mestrado em Oceanografia Biológica). Universidade Federal de Pernambuco, Recife, PE, Brasil.

Froelich, P. N. (1988), Kinetic control of dissolved phosphate in natural waters and estuaries: A primer on the phosphate buffer mechanism. Limnol. Oceanogr., 33 : (4), part II, 649-668.

Grasshoff, K. et al. (1983), Methods of seawater analysis. 2.ed. Verlag Chemie, New York.

Grzetic, Z.; Precali, R.; Degobbis, D. et al. (1991), Nutrient enrichment and phytoplankton response in a Adriatic karstic estuary. Marine Chemistry, 32 : (2/4), 313-331.

Hansen, D. V. and Rattray Jr, M. (1966), New dimensions in estuary classification. Limnol. Oceanogr., 11 : (3), 319-326.

Howarth, R. W. et al. (1988), Nitrogen fixation in freshwater, estuarine and marine ecosystems. 1. Rates and importance. Limnol. Oceanogr., 33 : (4), part 2, 669-687.

Ketchum, B. H. (1967), Phytoplankton nutrients in estuaries. In- Estuaries, ed. Lauff, G. H., Washington : American Ass. for the Advancement of Science. pp. 329-335.

Koening, M. L. (1983), Biomassa e fracionamento do fitoplâncton em viveiros de cultivo de peixes(Itamaracá-PE). Dissertação (Mest. Criptógamas). Universidade Federal de Pernambuco, Recife, Pernambuco, Brasil.

Legendre, L. and Rassoulzadegan, F. (1995), Plankton and nutrient dynamics in marine waters. Ophelia., 41, 153-172.

Legovic, T.; Zutic, V.; Grzetic, Z. et al. (1991), Eutrophication in the Krka stuary. Marine Chemistry, 32 : (2/4), 121-135.

Macêdo, S. J.; Lira, M. E. F. and Silva, J. E. (1973), Condições hidrológicas do Canal de Santa Cruz, Itamaracá-PE. B. Rec. Nat., 11 : (1/2), 7-32.

Macêdo, S. J. de (1974), Fisioecologia de alguns estuários do Canal de Santa Cruz (Itamaracá-PE). Dissertação (Mestrado em Fisiologia Geral). Departamento de Fisiologia Geral do Instituto de Biociências, Universidade de São Paulo, São Paulo, Brasil.

Medeiros, C. (1991), Circulation and mixing processes in the Itamaracá estuarine system, Brazil. $\mathrm{PhD}$ Thesis. University of South Carolina, Columbia, U.S.A.

Millero, F. J. and Sohn, M. L. (1992), Chemical Oceanography. CRC Press, Boca Raton. 
Paerl, H. W. (1995), Coastal eutrophication in relation to atmosphera nitrogen deposition : current perspectives. Ophelia, 41, 237-259.

Parsons, T. R.; Takahashi, M. and Hargrave, B. (1984), Biological oceanographics processes. 3. ed. Pergamon Press, Oxford.

Passavante, J. Z. de O. (1979), Contribuição ao estudo dos dinoflagelados da plataforma continental de Pernambuco (Brasil). Trab. Oceanogr. Univ. Fed. Pe., 14, 31-54.

Rasmussen, B. Stratification and wind mixing in the southern Kattegat. Ophelia, 42, 313-334.

Rhee, G. Y. (1978), Effects of N: P atomic ratios and nitrate limitation on algal growth, cell composition and nitrate uptake. Limnol. Oceanogr., 23, 10-25.
Smith, S. V. (1984), Phosphorus versus nitrogen limitation in the marine environment. Limnol. Oceanogr., 29 : (6), 1149-1160.

Strickland, J. D. H. and Parsons, T. R. (1960), A mannual of sea water analysis. Bull. Fish. Res. Bd. Can., 125, 1-205.

Teixeira, C. and Gaeta, S. A. (1991), Variação nictemeral da clorofila "a", produção primária do fitoplâncton e fatores ambientais da região de Ubatuba (Lat. 23 30'S, Long. 45 06'W). Bolm. Inst. Oceanogr. S. Paulo, 39 : (1), 15-24.

Received: August 26, 1999; Revised: September 12, 2000; Accepted: June 27, 2001. 